\title{
Globalization and Cultural Transformation: The Case of Bangladesh
}

\author{
K. M. Atikur Rahman ${ }^{1}$ \\ ${ }^{1}$ Department of Political Science, University of Dhaka, Dhaka, Bangladesh \\ Correspondence: K. M. Atikur Rahman, Department of Political Science, University of Dhaka, Dhaka 1000, \\ Bangladesh. Tel: 88-172-179-2121. E-mail:km_kasira@yahoo.com
}

Received: Janaury 27, 2013 Accepted: February 24, 2014 Online Published: April 14, 2014

doi:10.5539/ach.v6n2p1 URL: http://dx.doi.org/10.5539/ach.v6n2p1

\begin{abstract}
Globalization is currently an important phenomena subjecting on economic activities, socio-cultural dimension, political aspect and so on. This paper is made mainly on cultural changes focusing the impact on moral issue and lifestyle in the Third World. The study finds the domination of Western culture on all lives that erode cultural heritage and moral values. There has been creating consumerism by which western lifestyles are on diffusion. The specific objective of the study is to analyze how globalization rapidly transforms the social values and living pattern in the traditional societies. There have been some negative aspects; but modernization process is positively functioning as well. This study is a descriptive type of work and is conducted in qualitative approach. Though in-depth observation tool is used as a primary source, most of the data is mainly collected from secondary sources (book, journal article, official records, and media report). The study findings would be helpful for the Third World people to be aware of cultural hybridization in the age of globalization. It is thought that some new ideas and information may be added into social sciences.
\end{abstract}

Keywords: cultural hybridization, consumerism, western culture, moral values, lifestyle, erosion, McDonald's, cultural heritage

\section{Introduction}

\subsection{Introduce the Problem}

Bangladesh is densely a populated developing country. There was a rich cultural heritage in this land of its own. About 87 percent people of the nation are Muslims. Its original culture emerges from mainly Islam and Hinduism of West Bengal. The customs, manners, arts of the Hindus are mixed with the Islamic ideology that is known as Bengali culture. Ethnically all the people belong to the homogeneity of their cultural history. Most of them speak Bangla and their behavioral pattern, festivals are almost same. So Bangladesh is a land of homogeneous culture which now is being transformed into hybridization.

Fast changes are observed at cultural level, as a result of increasing globalization and reforms in the third world countries in recent decades. It is also observed that culture is being changed rapidly from late 90s. Though its changing process started just after World War II, western culture dominates over the rest of the world since early in twentieth century. This is presently viewed that it has been one kind of cultural imperialism which mainly based on capitalism. The prominent popular American i.e. Western cultural symbols such as Coca-Cola, blue jeans, rock music and McDonald's Golden Arches are getting spread all over. Gradually, the world is transforming into a single global culture. According to Tomlinson (1991), such cultural merging represents a form of neo-imperialism that will destroy cultural variety. In this sense, cultural globalization possesses a threat to nation states. Behavioral pattern and lifestyles in Bangladesh gets a new form influenced by Western culture. There was a distinct pattern of its cuisine, dress, custom, manner, value for a long time. But in a couple of decades there is a visible change in all the matters. Fast food, T-shirt, Jeans, soft drinks have been now the integral part of young generation. Cultural heritage is on eroding trends by Western world and the TNCs rapidly. There are some positive impacts globalizations on lives, but negative impacts are sharply bigger in these changes. The negatives are reflected on the rising trend of cultural violence, armed reactions to cultural imperialism and increasing dominance of a consumer and self-oriented society, leading to erosion of spiritual and community oriented values worldwide (Parker, 2005a:218). In Bangladesh, socio-political violence, communal conflict, murder, women repression, changes of 
values and lifestyles have been a great momentum to the people of all walks. The study has been selected on the concerned of this cultural conflict and transformation in Bangladesh.

\subsection{Literature Review}

A good number of books and articles have been reviewed to collect required data and to prove the importance of selecting the study. These are:

- Cultural Imperialism, by Jhon Tomlinson (1991).

- Globalization and culture, by Jhon Tomlinson (1999).

- Globalization, Governance Reforms and development: An Introduction, by kameshwar Choudhary (2007).

- The Islamic Conception of justice, by M. Khadduri and so on.

Two articles have also been studied such as:

- By reviewing 'Globalization and Culture', by Girish Mishra (2004), it is found that changes of lifestyle domain and Indian cultural issues have been focused; but moral values in the age of globalization didn't get priority at all.

- In 'Globalization and the Moral Issue' by V.V.Maliavin (2012), these are seen that moral status, modernity, humanism and spiritualism were mostly emphasized; but changes of lifestyle pattern could not be highlighted. The two studies partially represent the cultural changes in Bangladesh. This study is actually selected on the basis of the gaps mentioned above.

\subsection{Importance of the Study}

Several books and articles published in Bangladesh have been reviewed which are mainly focused on arts and music culture, folk culture, cultural background and heritage, archaeological matters and Islamic ideology and so on. But the transformational aspects of moral values and lifestyles have hardly been discussed. Moreover, it is being thought that the westernizing trends of moral values and life patterns rapidly getting changed through globalization are to be opened up before the people in the developing countries so that they can be aware of. The policy makers may be considered to be enriched by the findings to formulate the state cultural policy and the social workers would probably be able to do welfare deeds of the society in accordance with the touches of the study findings. This study topic has been selected for the thoughts of the significances mentioned above.

\subsection{Objectives of the Study}

Generally the paper aims to explain the impact of globalization on social culture. There have been set up several specific objectives of the study which are stated below:

- To analyze the transformation of moral values and behavioral pattern in the age of globalization.

- $\quad$ To explore the western influences on lifestyles in the developing societies like Bangladesh.

\subsection{Hypothesis}

There have been set up three hypotheses in the study which are stated below:

- Western culture dominates the rest of the world

- Globalization erodes the heritage of moral culture

- The more digital technology will be extended, the more cultural hybridization will be expedited.

\section{Method}

The paper is entirely shaped and typed on the basis of narrative manner. This is a study of empirical method which has been conducted in qualitative approach. Mainly secondary sources have been used for data collection based on the analysis of various documents. Books, journal articles, records of governmental and non- governmental organizations, media reports are the main sources of data. Besides, in- depth observation is another source of primary data.

\section{Results}

There have been found out several findings from the study which are stated below:

- Though globalization started its journey following the baseline of Washington Consensus, it has presently been a phenomenon of inevitable natural process. 
- Digital technology, electronic Medias, English language and transnational enterprises play a vital role in globalization process.

- Western culture is dominating all over the world.

- The culture of developing countries is merging with that of the North getting new concept of cultural hybridization. As a result, cultural heritage is on erosion and new cultural values are being established in Asia, Africa and Latin America.

- Western lifestyles are getting popularity rapidly in the developing nations

\section{Discuss}

\subsection{Conceptual Framework}

In a wider sense, culture is the totality of values, belief, lifestyle, cuisine, behavior, etiquette of the people of a society. It is being changed rapidly as a result of ongoing globalization and reforms in the developing nations in the recent decades. Three major paradigms of culture change under globalization (Choudhary, 2007a). Cultural homogenization, reflects the neo-liberal hyper globalist view of homogenize cultural changes. But cultural homogenization is regarded as cultural imperialism in the context of neo-Marxist view. Cultural heterogeneity is viewed to provide more cultural choices to individuals. But hybridization paradigm is said to be embedded in the transformation list perspective. The paradigm of cultural clash provides a cultural in perpetration of current cultural changes. Three clashing notions of cultural change in the era of globalization which includes cultural homogenization clash and heterogeneity or hybridization paradigms (Choudhary, 2007b).The homogenization paradigm emphasize on global interdependence and inter connectedness for cultural standardization uniformization and compassion in to a single global culture. Its actual aim is to increase the homogeneity of world values like rationalization, commoditization democracy and human rights. Western cultures are reflected on the people of the rest of the world changing the lifestyle and consumption patterns in the symbolic norms of Coca-Cola, rock music, blue jeans, sleeveless kameez and so on.

Berger (2002) observes an emerging global culture which, in origin and content, is mostly of Western and American provenance. Emerging global culture is penetrating the rest of the world through diffusion at both elite and popular levels. He talks about two types of elite vehicles of diffusion. First is the 'Davos culture' which signifies an international culture of business and political leaders, Davos being the locale of the annual World Economic Summit. Those participating at the Summit are socialized in its culture and carry the cultural baggage from there for diffusion in their countries. Another elite vehicle of diffusion is represented by the 'faculty club culture' signifying globalization of the Western intelligentsia. It consists of a variety of careers such as academic networks, foundations, NGOs.

\subsection{Present Global Culture}

The new global culture signifies deterioration and the emergence of a borderless world. Globalization has greatly increased the means through which nationals of one country actively take part in another country's cultural, economic and political life. Some hold that this leads to consumer culture which is not plain consumption (Naim, 2002). One society is influenced by consumption habits of other societies. These influences are being more and more powerful. Consumer culture means the bundle of goods and services consumed, and its composition are not determined mainly on the basis of real needs and the capacity of payment.

The goods and services are consumed which are justified in the eyes of his peers his social status. At times, what one calls 'band wagon' and 'snob' effects determine them. Aesthetic pleasure may lead people such consumption and that is regarded as show piece or fashion item. The youths are the main group to be on consumer culture. Under capitalism, the aim is to sell as much as possible to maximize of profit (Mishra, 2004a). In order to do this advertisement becomes necessary not to disseminate knowledge of the productions but to create a demand. Fashion shows, ramp show, employment of glamorous models, actors, sports meet are the ways to attract potential consumer. The media industry (radio, television internet, movies mobile phone) increases the power of advertisement. Credit facility enables people to meet their wishes into demand. Consumerism is regarded as the principal form of self-expression and the major source of demonstrating one's indent. Now a days commodified value are powerful more than moral values in the selection matters of peer groups and relatives. Fashion and lifestyle play a vital role in the process of social differentiation and politics.

\subsection{Technological Influence on Culture}

Amusing technology provides some goods and services in era of globalization generating cultural complexity. Soft drinks, junk foods replace the traditional food items (tea, milk, local fruits, rural handmade cakes and so on). This 
food culture has already been a part of socio-relational activities. Carbonate, excessive sugar, alcohol, margarine, fatty ingredients are indeed the matters of health hazards such as heart disease, hyper-tension, diabetes, cancer, obesity have been subject to a global concern. Bottled water has become a pervasive global business, and bottled water consumption continues to increase rapidly (Wilk, 2013). The technology of movie and music are now at very advanced level and these amusing items are also getting social customs producing the thoughtless and demoralized horizons. Smart phone, internet connected computer, mp3 player all the digital devices are forwarding created a new era of pop culture where positive enjoyment is rarely active. South Asian recreational heritage of folk song, theater drama, gossiping, local sports played a vital role in mental development are under extinction threats. But digital refreshment can play a little role in building up spirit and mind. According to Benjamin R. Barber (1996):

Films are central to market ideology. Watching them reveals a sameness pervading McWorld that seems as suffocating as the invisible 'either' that was once thought to have suffused the entire cosmos and to have given it the invisible infrastructure that made Newtonian physics plausible. Films are McWorld's preferred software, but television rather than the cinema is its preferred medium; for with television, McWorld goes one on one, the solitary individual and cyberspace confronting one another in exquisite immediacy - with the screen as the perfect nonmediated (im-mediate) medium. Where cinema is limited in time and place, television is a permanent ticket to ceaseless film watching anytime, anywhere. It is a private window on McWorld.

Now-a-days religious activities (publicity) are being performed through digital media especially television on the way of advertising and other usual programs. Religious devotees and followers can find the desired information and activities easily not attending the spot. Television companies want to make money anyhow exploring newer programs focusing emotionally weak point of children, juveniles, women and youths. Consequently it is viewed that all the people of different ages are getting habituated in their desirable programs. Children are affected over their study matters and women leave their home duty to seat before the television set for enjoying the addicted serials or others. The young generation is adversely addicted on Face book, Twitter, Google+, Blogs as well as cell phones (Smart Phone, iPhone). These are used for passing leisure time and making friendship occurring meaningless love which affects their spiritual strength and importance for reading. Not only the western countries but also the Muslim world cannot go beyond the then McCulture. Will force, thinking strength, real pleasure of today's youths are seriously affected through the addiction of visual media. The on-going process of globalization lays great stress on technology, which implies two things, namely, "machinery and the mental habits conducive to a dead thinking."Examples of such thinking are everywhere. We build mechanical connections between people and we call infrastructure of community. We convert the natural world into massive data sets, and we call that ecological understanding. We send trillion-dollar capital flows streaming daily through the world, seeking nothing more than their own mathematical increase, and we call that "social development. This is machine thinking" (Talbott, 2001).

\section{According to John Tomlinson (1997):}

"The relationship between globalization and culture has been approached from a different angle. The relationship between the two is not unilinear. Both of them influence each other. Globalization lies at the heart of modern culture; culture practices lie in the heart of globalization. This is the reciprocal relationship."

Globalization alone cannot form a cultural mixture or new element of cultural dimension because of absence of its active and direct performance. Yet, it breaks down the national boundaries to expedite the flow of goods and services that are the running sources of cultural transformation. Legal and illegal flows of goods and services have been common feature of the world and here is observed that irrational flows increase crimes, corruption and socio-political unrest in the developing countries

\subsection{Globalization and Erosion of Values}

There is a growing influence of global media through television, internet, etc. in shaping a new culture of young generation all over. The role of social institutions like family and state in shaping the values, attitude and behavioral pattern is declining fast. Programming of the global media is largely dominated by U.S. It is feared the European/US culture with erode and displace other cultures (Choudhary, 2007c). Family itself is breaking down owing to industrialization and urbanizations resulted in creating nuclear families. Most of day time, many of the parents stay in their offices leaving their children alone at home or to their servants. As a result, those children are being threatened in the development of their moral values. Now a days, television and cell phone are presently the main recreational devices to all the people. These modes are shaping the values of the new generation. Most of the visual programs are produced based on meaningless love, romanticism and sex which build the character of the young boys and girls negatively causing violence, rape, acid throwing etc. Thus digital media erodes conventional moral education. 
Internet/information technology cuts all boundaries. Life in the cyber world is quite vibrant with online group (yahoo groups, msn groups) and internet (social networks) communities like Fraudster, Orkut, Okstupid and so on. Besides, the web world is used for advertising and sales for profit. The media is generally said to shape the way most of us live our lives affecting the way we think, act and dream (Steven, 2005). In Bangladesh there are about 10 lakh users of Face book. Besides, the numbers of Twitter, Google+ users are not small at all. Most of the users are youths who pass their important time with the friends of Face book, Twitter. It is observed that such a connectedness with this media is mostly meaningless but romantic pleasure. Teen- age boys and girls are seriously addicted to social networks which have already been a great social problem. Though social media is a platform of friendship, it spread pornography, meaningless love, frauds, and lesbianism. Besides this web world is sometimes responsible for destructive movements and crimes.

Ahmad (2004) notes the high intensity of invasion of the household is done by the global electronic media, particularly television. This is changing not only thought process but also the living systems, consumption patterns, and even the very nature of such human desires as love and sexuality. Watching TV operates as a study circle for acquisition of certain sorts of ideology and cultural taste. Electronically mediated culture has a wider reach covering even the poor families, particularly in urban areas, who participate as passive, fantasizing consumers. Mainly women and children are affected more by TV. There is no sufficient open space for recreation in urban areas. So women and children remain sitting before TV set and computer machine for a long time. Watching TV is a root cause of obesity of women and children. Besides, diabetes, hyper tension, heart disease, pains are the bad outcomes of sitting long time before TV and computer sets. Educational matters of children are hampered seriously and capitalistic attitudes are grown through visual media. Love and sex based TV entertainment leads the children into demoralizing activities.

\subsection{Media Impact on Moral Character}

There is increasing control and monopolization of the sectors by a handful of transnational corporations, which treat media as any other business, based solely on the principle of profit maximization. Moreover, the rapid integration of global telecommunication systems has strengthened the symbolic and psychological means of control of the neo-colonial powers in pushing mainly the American culture with the ideologies of consumption, instant gratification, self-absorption and global capitalism. There is increasing commercialization of the media which focus on sex and violence-based entertainment. Pressure is exerted by media TNCs to open up the third world's domestic media sector (both electronic and print) for foreign participation. The government of India-has, for instance, made policy changes to allow entry of TNCs in the electronic media (TV) (Mukharjee 2003). The opening up of the print media seems to be next in line, though, at present, there is stiff resistance to it. Bangladesh also opened up its market for the electronic media (television). At present about $200 \mathrm{TV}$ channels are in operation. Of these channels, above150 are being conducting by TNCs and they are doing business comfortably. Their programs are mainly focused on sex, love and violence which are eroding the heritage of moral culture. Bangladesh culture is mostly derived from Islam, but it is currently under a great threat.

Modernity means positivity that leads people onto fair track, and conscience and vigor here work for the sake of a spiritual and stable society. Both intrinsic and extrinsic beauty is working of course a striking force creating a real pleasure for human being. Whereas post modernity itself is a derailed phenomenon in which nihilistic tendency and aesthetics make a painful confinement around public lives. Increased number of people across the ideological spectrum believes that society is in deep moral trouble. This disheartening signs are everywhere; the breakdown of the family, the deteriorating of civility in everyday life, rampant greed at a time when one in five children is poor, an omnipresent sexual culture that fills the television screen with sleaze (Lickona, 1993 and Thompson, 2011). Victimless crimes along with violent activities hit repeatedly people's spiritual kingdom leading an extreme vacuum into the societal heart. Post modernity is the frustrated modernity that has lost its vigor in esthetical contemplation and has forgotten itself in play or, to be more precise, the semblance of a defying and dangerous action which is all the more daring because nothing is at stake and man alienated from being really runs no risk. The measure of postmodern playfulness is, in fact, irresponsibility (Maliavin, 2012b). When modernity is driven on the basis of aesthetic outlook, it costs high but there is a little spiritual pleasure negatively creates frustration and mental unjust causing various kind of crimes. This feature is prevailing all over the world like Bangladesh.

The growing critical approach focuses on the increasing monopolization an commercialization of media which, in political terms, is regarded as having highly depolarizing effects and thus considered to pose a serious threat to public sphere and democratic order based on citizen participation in public agenda setting, Herman and McChesney (1998: 9) observe that 'the commercial model being innately owned and relying on advertiser support, tends to erode the public sphere and to create a "culture of entertainment" that is incompatible with a democratic order. Media outputs are commodities and are designed to serve market ends, not citizenship needs.' The media is 
getting integrated into the capital accumulation process, liven media professionalism is rarely found to be neutral and 'tends to reflect the interests not only of media owners and advertisers, but of business and powerful social forces as well'. It is true that there are $27 \mathrm{TV}$ channels in Bangladesh which are run for the interests of owners and advertisers. Besides, political biasness makes the media industry questionable. Corporate culture in media world is a threat to fair journalism.

\subsection{Cultural Violence and Globalism}

Cultural violence is a daily terrible phenomenon in both national and international levels. Egypt, Bangladesh, Pakistan, Palestine, India, Myanmar, Afghanistan, Iraq, Yemen face such a violence. The negatives are reflected in the rising trend of cultural violence, armed reactions to cultural imperialism and increasing dominance of a consumer and self-oriented society leading to erosion of spiritual and community-oriented values worldwide. There are deferent types of violent responses to cultural clash such as terrorism, vigilantism and extremism (Parker 2005b:218). Militancy/extremism is a great problem in the present world. Pakistan, India, Myanmar, Sudan, Lebanon, Syria, Afghanistan are the victims of these offensive activities. Clashes between different ethnic/communal groups are nothing but clash of civilization. It may be regarded as a cultural conflict as all the communal groups belong to different cultures. People are rushing towards the earthly assets being influenced by consumerism. Because social status is now dependent upon material assets and for gaining the then money and assets, people are getting involved in all demoralized activities.

Modernity is not a messenger of some universal human nature. On the contrary, it is a companion to the deepest crisis of human identity for the measurement of modernist humanity is man's negation of oneself, dehumanization (Maliavin, 2012a). Self-centric people are moving towards capital/money feeling no human's grief. Sometimes through exploitation of the poor, capitalism is being established day by day. Inequality and injustice have been gruesome aspects in the developing countries like Bangladesh. The state authority mostly patronizes the riches instead of the poor. In all spheres, the lower class people are deprived from state and social right and opportunity. As money is regarded as the symbol of socio-cultural status, so all are getting involved in money making activities in both legal and illegal ways.

\subsection{Changing Trends in Lifestyle}

Cable television networks build up a strong environment of commercial culture. Culture has itself own identity, values and modes; but one stage these cannot remain in the original shape when commercial trends are intruded. Each drawing room contains at least a latest model television set aired various trendy programs round the clock based on foreign lifestyles and values developing 'dialectic mentality' throughout the world. Reality television problematizes distinction between reality image; pure and hybrid; and authentic and foreign. Reality based programming allows for greater contestation over who defines realities both politics and cultural (Kraidy, 2010 and Carr, 2013). Family's original values when cannot adjust the actors or actress of media world, they fall down in conflict situation. The growing children don't find the right way to be cultured and civilized; behavioral discrimination misleads them into a dark world.

\subsection{Tastes and Fashions on Change}

There are, broadly speaking two views about the way consumer culture goes global and is able to influence and dominate an individual. First, individual identify is linked to culture. Capitalism transforms people into consumers by altering these self- images. This structure of wants is this so that they serve capitalist accumulation (Robinson, 1997). Second, the phenomenon, known as McDonaldization, constitutes the other view. This is the process by which the principles of fast food restaurant chain McDonald's are fast bringing the entire world into their fold. They include efficiency, calculability, predictability and control of human being through application of materials technology (Featherstone, 1993). Not only McDonald', but also other fast food chain restaurants (pizza hut, KFC) changes the human behavior by applying the ultra-modern technology. Actually behavior and lifestyles are availing uniformed shape eroding the heterogeneity of global culture.

Material technology leads to maximum deskilling of workers and directing consumers by means of fixed manner displays, limited options, uncomfortable seats, inaccessible toilets. Consequently, much talked about sovereign consumers are made docile conformists. Thus McDonaldization leads to a reordering of consumption and production and rationalization of previously informal and domestic practices in order to bring about greater conformity (Waters, 1995). Sphere of consumption is categorized into two parts, First, fashion in mass markets, which accelerate the pace of consumption in dress, adornment and decoration as well as a wide spectrum of lifestyle and recreational activities (Sporting habits, pop music, video games). Second, the importance of services vis-a-vis goods in individual level continuously increases. These services include personal, business, educational and health care. The life span of goods and services is shortened resulting in the increased valued of demand. With 
other nations in Bangladesh fashions and tastes living pattern are on rapid change. Burger, kebab, sandwich, pizza, soft drinks, soup are spreading among the young generation in urban areas. These are now the symbolic items of status to the elite class. Though the fast foods are not so healthier; but they are getting popularity instead of conventional local items (tea, local cake, shingara, poori, and so on) which are undoubtedly healthful. People emphasize the values and virtues of instantiate (instant and fast foods) and of disposability (cups, plates, cutlery, packaging etc.) Fashions in dress, furniture, home are greatly acquainted feather in all level of the country.

Shopping is a habit and a mode of leisure period. When fashion is a symbol of social status, money matters and social values get little priority. Actually, western blue jeans, ti-shirt, Skirt, Nike and Adidas sporting shoes, sleeveless kameez are the major fashion items in the oriental societies. It is impossible to lead the lives without decorative and well-furnished home. Such a consumer culture leads the lives complicated as all the people cannot afford there. Besides, all types of ceremony and festivals demand these fashions which are different to be managed well.

\subsection{Consumerism in Economic Culture}

An important feature of present-day globalization is the advent of consumer credit society. Till the arrival of credit cards, the cash at his disposal or his ability to raise loans limited a person's consumption. Credit cards have played a very vital role in tremendously extending this limit. A person can now buy goods and services even if he does not have cash at his disposal or the prospect of immediately securing a loan. Credit cards have given a tremendous boost to consumerism and pushed households into debt (Manning 2000). Young businessmen in Bangladesh also accept this in wider range and it is yet limited within urban areas. At the beginning stage, the banks indulge deception to gather desired card customers. Sometimes, they seem to be trapped in debt web. Now credit cards spread very fast in Bangladesh as per the symbol of modernity and easy banking transaction. During the present era of globalization the concept of work place is undergoing as sea change. The old concept of fixed working hours is giving way to working according to convenience and transferring the work through internet (Mishra, 2004b). In developed nations the employees remain inconstant touching with their superiors by dint of information technology. The city character is being enormously changed. With the developed countries, the cities will become the places where people go for recreation and civic activities. Managerial professionals and politicians in Bangladesh give directives to the subordinates over mobile phones and internet. Official letters, decisions, orders are served though information technology instead of conventional postal channels. Application for jobs and admission into educational institutes take momentum in using mobile phone and internet uses without being moved relevant spots. Beside, online shopping or telemarketing is being vigorously promoted. Without only kitchen goods all are marketed online and over cell phone. There are several online shopping sites (bikory.com, cellbazar, rokomary.com and so on) that are getting popularity even in small towns of Bangladesh.

Obviously, the world of advertisements has become intermingled. TNCs backed big advertisement companies are on consistent efforts to expand their product markets in the non- western world. Such products and services are in fact the sources of infusion of global culture. Children, young men and women are their main target groups so that they can be the consumers of that habituated brand items for a long time. People who focus on marketing strategy, various predictive techniques, and customer's life time value can raise myopia to a certain extent. Kotler and Sing (1981) coined the term marketing hyperopia, by which they mean a better vision of distant issues than of near ones. Young women are naturally fashionable; fashion companies change their model and design repeatedly and aesthetically to attract fresher's and hold up the olds. In this connection, world famous advertising companies play a pivotal role. Eye-catching toys and tasteful processed foods are globally produced to make a rush of children to shops. Such these commercial business targeting children and youths spread consumerism hollowing out the individual or family savings and encouraging extra income illicit or implicit ways. A wide circulation of goods and services depend mostly on advertisement. It is now an integral part of business. It is rarely conducted in noble's motives but in the sake of business. A good program also becomes disgusting owing to excusive advertisement. Beauty queens, models are made involved in brand promotion, which mostly based on worthless love, romance and sexism. With the development of corporatism, advertisement industry has been moving forward sharply in Bangladesh with other countries. The growth of entertainment programs and consumerism is the real outcomes of this industry.

\subsection{Religious Belief on Threat}

There is a great deal of apprehension in many developing countries about the increasing invasion by American culture. A symposium organized by the Juma Al Majid Centre for Cultural Heritage brought this out. The topic was 'Arab culture in a Globalization Era.' Dr Jassim Mohammed Jirjees, Asstt. Secretary-General of the Centre noted: 
Globalization is a recent and sensitive issue that touches and affects Arabs and Muslims. I wonder whether globalization is a bridge of brotherhood among superpowers and other small countries, or is it a trap set for nations who don't understand what globalization is, or is it a lack of belief in nationalization, or does it dedicate everything for the good of the U. S. (Zaza, 2002a).

Dr Jassim Asfour, General Secretary of the Cultural Council, Egypt said.

Globalization is another term for capitalism and imperialism and all Arab Muslim need to consider it an imminent danger that is endangering our political, social, cultural and economic stability. The stability has become greatly affected by all multinational and transnational companies that have spread all over the world markets. These companies are penetrating any country's stability without even taking into consideration the political independence, national integration or national identity (Zaza, 2002b).

Just like the Arab World, there has been viewed that the implications of globalization on the Islamic ideology are getting threatened in Bangladesh and other oriental Muslim countries through raising the materialistic behaviors. Islamic life styles are on rapid changes in consequences of skin fitted dresses (jeans, ti-shirt, and sleeveless kameez) that are gaining popularity both in rural and urban areas. There is a visible change in festivals such as 31 st night, Pahela Baishakh (first day of new Bengali year), birth day and marriage day celebration and so on. The electronic media broadcasts the programs which are mostly based on western ideology and most of the Bangladeshi people are profoundly fond of them. These cultural programs cannot be adjusted or matched with Islamic values; but the two cultural values are being merged and created a new mixture of culture.

\subsection{Hybridization of Languages}

With the march of the process of globalization, there is a change in the character of various languages; especially those of less developed countries. To bring home this point, one may look at Hindi or the kind of English spoken or written in India; there is a perceptible change. New words have entered the vocabulary of daily usage (Tuhus, 2002a). English is a dominating language which is used in business, diplomacy, computer and internet and many more. English of American variety gets fair popularity all over the world especially in South-east Asia. About eighteen per cent of the total people of the world currently speak English. There are many studies attesting to the difficulty of acquiring morphological case in second language acquisition, this result supports the idea that languages adapt to the cognitive constraints of their speakers, as well as to the sociolinguistic niches of their speaking communities (Bentz, 2013). Moreover, one billion people will learn English in this century. But the mother language is being polluted in terms of accent, tune, word breaking or changing, meaningless mixture with other languages and so on. By the influence of globalization Spanish, German, French, Arabic are gaining to push down and about 3,000 languages are under threat of extinction.

Globalization has led to outside groups interested in extracting minerals, timber and oil and natural gas coming to areas and communities barely exposed to external influences. Wherever they have established a position of dominance, they have seen to it that their own languages are used in schools, administration and the media at the expense of local languages (Tuhus, 2002b). English medium schools are mushrooming in the developing countries like Bangladesh as the rich guardians think English has tremendous job prospects and global values. English is undoubtedly important; but mother language is the principal mode to develop the moral culture. English dominated globalization increases pride, egotism and zealousness in the non-western countries.

\section{Conclusion}

It is finally viewed that globalization touches all human lives and plays strong role in transformation of moral values and lifestyles in Bangladesh as well as other developing countries. The process brings some opportunities; but its root challenges for the poor nations are the gruesome matters as well. Advantages of globalization process have to be availed by overcoming the obstacles. No nations including Bangladesh individually are able to attain desired wellbeing without battling the challenges of globalization because of its collective manner. Without negotiating skill, tactful diplomacy, ICT knowledge, technology transfer, proper policy management, human resource and so on, no country avail the global opportunity. The policy makers can be helped by the different data and information resulted in the study. This study may enable the people of all walks awaking of cultural hybridization. Social and cultural workers can get valuable information to formulate cultural policy and action plan. The study may be useful for both the formal and informal researchers in advancement of new dimension. There are plenty of data that is important for the students of social sciences. It is evident that cultural liberalism is as essential as protectionism. 


\section{Acknowledgement}

I would like to thank to my supervisor of M .Phil Program, Professor Dr. M. Abdul Wadud Bhiuyan for the valuable guidance and advice. Besides, I would like to thank to Associate Professor Dr. M. Rabiul Alam, Hamdard University Bangladesh for creating moral courage and valuable information while writing the paper.

\section{References}

Ahmad, A. (2004). On communalism and Globalization: Offensive of the Far Right. New Delhi: Three Essays Collections

Barbar, B. R. (1996). Jihad Vs Mc World. New York.

Bentz, C., \& Winter, B. (2013). Language Dynamics and Change. Global Media Journal, 3(1), 1-27. http://dx.doi.org/10.1163/22105832-13030105

Berger, P. L. (2002). Introduction: The Cultural Dynamics of Globalization. In P. Book., L. Berger, \& S. P. Huntington (Eds.), Many Globalizations: Cultural Diversity in the Contemporary World. London and New York: Oxford University press.

Carr, D. (2013). Reality Television and Arab Politics: Contention in Public Life. Global Media Journal, 12(22).

Choudhary, K. (2007). Globalization, Governance Reforms and Development: An Introduction. In K. Choudhary (Ed.), Globalization, Governance Reforms and Development in India. New Delhi: Sage Publications.

Featherstone, M. (1993). Global and Local Cultures. In J. Bird (Eds.), Mapping the Futures: Local Cultures, Global Change (pp. 169-187). London.

Kotler, P., \& Sing, R. (1981). Marketing Warfare in the 80s. Journal of Business Strategy, 1(3), 30-41.

Kraidy, M. M. (2010). Satellite television's Reinvigoration of Arab Polities Reality Television: Arab Politics: Contention in Public Life. London: Cambridge University Press.

Machesney, R. W. (2001). The Political Economy of Global Communication. In R. W. Machesney, E. M. Wood, \& J. B. Foster (Eds.), Capitalism and Information Age: The Political Economy of Global Communication Revolution. Kharagpur: Cornerstone Publications.

Maliavin, V. V. (2012). Globalization and the Moral Issue. Retrieved from http://tkugloba.tku.edu./inglish /doc-c/Globalization.htm

Manning, R. D. (2000). Credit Card Nation: The Consequence of America's Addiction to Credit. New York.

Mishra, G. (2004). Globalization and culture. Online Journal of Radical Ideas. Retrieved from $\mathrm{http} /$ /iis-db.stanford.edu/pubs/23328/lifestyles.pdf

Mukherijee, A. (2003). Audio-visual Policies and International Trade: The Case of India. HWWA Report 227. Hamburg: Hamburg Institute of International Economics.

Naim, M. (2002). The New Diaspora. Foreign Policy. July - August.

Parker, B. (2005). Introduction to Globalization and Business. New Delhi: Response Book.

Pieterse, J. N. (1996). Globalization and culture: Three Paradigms. Economic and Political Weekly, 31(23), 8.

Robinson, G. P. (1997). My Think, Perspective of Comodification on the World Wide Web. Retrieved from http://www.firstmonday.org/ issues/issue7_3/robinson/index.html

Steven. P. (2005). Global Media. Jaipur: Rawat Publications.

Talbott, S. L. (2001). Why not Globalization? Retrieved from http://natureinstitute.org/pub/ic/ic5/global.htm

Tomlinson, J. (1991). Cultural Imperialism. Baltimore: John Hopkins University Press.

Tomlinson, J. (1999). Globalization and culture. Cambridge.

Thompson, M. (2011). Developing Moral Values in Children: Observation from a Preschool. Ife Psycho logia, 19(2).

Tuhus-Dubrow, R. (2002). World's Languages are Fast Disappearing. Retrieved from http://www.globalpolicy.org/component/content/article/162/27570.html

Waters, M. (1995). Globalization. London.

Wilk, R. (2006). Bottled Water: The pure Commodity in the Age of Branding. Journal of Consumer Culture, 6(3), 303-325. http://dx.doi.org/10.1177/1469540506068681 
Zaza. B. (2002). Arab Speakers See Threat to Culture by Globalization. Gulf News.

\section{Copyrights}

Copyright for this article is retained by the author(s), with first publication rights granted to the journal.

This is an open-access article distributed under the terms and conditions of the Creative Commons Attribution license (http://creativecommons.org/licenses/by/3.0/). 